\title{
IAMJ
}

INTERNATIONAL

AYURVEDIC

MEDICAL JOURNAL

ISSN: $2320-5091$

Impact Factor: 6.719

\section{AN OVERVIEW ON ROLE OF ETHNOMEDICINE IN BOOSTING HUMAN IMMUNITY TO COMBAT VARIOUS VIRAL DISEASES}

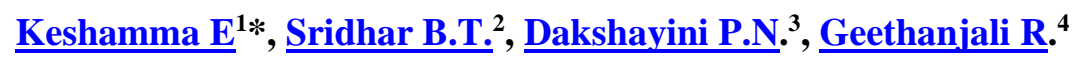 \\ ${ }^{1}$ Department of Biochemistry, Maharani Cluster University, Palace Road, Bengaluru, Karnataka, India \\ ${ }^{2}$ Department of Chemistry, Maharani Cluster University, Palace Road, Bengaluru, Karnataka, India \\ ${ }^{3}$ Department of Zoology, Maharani Cluster University, Palace Road, Bengaluru, Karnataka, India \\ ${ }^{4}$ Department of Botany, Maharani Cluster University, Palace Road, Bengaluru, Karnataka, India
}

Corresponding Author: Keshamma.blr76@gmail.com

https://doi.org/10.46607/iamj1609072021

(Published Online: July 2021)

Open Access

(C) International Ayurvedic Medical Journal, India 2021

Article Received: 13/06//2021 - Peer Reviewed: 24/06/2021 - Accepted for Publication: 25/06/2021

\section{Check for updates}

\begin{abstract}
Some of the medicinal plants valued in Ayurvedic Rasayana for their therapeutic potential have seen scientifically investigated with promising results. Several plant-based principles have been isolated with a potential immunomodulatory activity that can explain and justify their use in traditional medicine in the past and can form the basis for further research in the future as well. Hence, the present review of the literature study was planned to document common and easily accessible functional food plants that can modulate the immune system and are biologically active against several medical problems arising from respiratory tract infections and in addition this review will serve as a guideline to the general public to include important medicinal food plants in their daily diet for strengthening and improving their immune system and overall health. Based on the knowledge from this review of the literature study we hypothesize that plants may help individuals to overcome the infection by (i) modulating the body's immune system (ii) generating antiviral activity against the infection (iii) reducing other respiratory problems. A substantial number of plant extracts and phytochemicals have been explored for their antiviral property. Herbal preparations owing to their holistic approach strengthen the body's immune system, which in turn may help the body fight against invading infectious viruses. In this review of the literature study, we documented twenty functional food plants with immunomodulatory and antiviral properties that have been reported to induce the immune system in several ways. These mainly include liquorice (Glycyrrhiza glabra L.), garlic (Allium sativum L.), tea (Camellia sinensis [L.] Kuntze), ginger (Zingiber officinale Roscoe), turmeric (Curcuma longa L.), pomegranate
\end{abstract}


(Punica granatum L.), black pepper (Piper nigrum L.) and several others. Thus, the practice of ethnomedicine plays a pivotal role in boosting human humanity to combat various viral diseases and will also help human beings to protect against the current Covid-19 like pandemic situation.

Keywords: Ethnomedicine, Immunomodulatory, Antiviral, Onion, turmeric, Zinger, Garlic, Tea, Black pepper.

\section{INTRODUCTION}

Throughout history, mankind has been accompanied by infectious diseases that have, in one way or another, raised the question of its survival. Almost all the time, mutations in strains of influenza A viruses lead to the emergence of infectious diseases with new symptoms and consequences. Avian flu, swine flu and other zoonotic influenza virus infections in humans lead to diseases ranging from mild upper respiratory tract infections to severe pneumonia, acute respiratory failure syndrome and death. ${ }^{1}$ Each of them is initially regarded as a pandemic, but as soon as a treatment medication and a vaccine are developed, it is considered a regular seasonal flu. The coronavirus that led to the COVID-19 pandemic is similar to the pathogen SARS-CoV (a viral respiratory disease of zoonotic origin) that caused the epidemic of 2003. A drug for atypical pneumonia that has passed clinical trials is yet to be developed. In 2020, humanity is being forced to return to the unfinished solution of the problem, whose initial conditions will be amended with new criteria. This SARS-CoV-2 virus has affected many people, not only in China but spreading to almost all countries and territories in a short time. ${ }^{2}$

Complementary and alternative medicine offers a wide variety of herbal plants, which may serve as a key to unlock the many mysteries behind human pathologies. According to a WHO report, $80 \%$ of the population in developing countries depends on traditional plants for health requirements. ${ }^{3}$ Several medicinal plants have been explored and found potential against lethal viral infections. Ethnomedicinal literature documents several such herbal plants claiming broad-spectrum antiviral activity. In the light of the advancing technological tools at disposal, exploration of potential antiviral activity of numerous medicinal plants has acquired a phenomenal pace with the emergence and re-emergence of highly infectious viruses. Thus, the present review aims to document common and easily accessible functional food plants that can modulate the immune system and are biologically active against several medical problems arising from respiratory tract infections. Furthermore, this review will serve as a guideline to the general public to include important medicinal food plants in their daily diet for strengthening and improving their immune system and overall health.

\section{Herbs with Immunomodulatory Properties}

The human immune response is the body's most important defence mechanism against disease and the survival of humans is greatly dependent on this system of fighting against foreign pathogenic microorganisms, including viruses. The possible immunomodulatory function of plants is a recent concept in the field of phytomedicines. Immunomodulators not only enhance humoral and cell-mediated immunity but also activate non-specific immune responses such as activation of the natural killer (NK) cells, macrophages, granulocytes and complement systems, which enhance resistance to infections non-specifically.

Table 1 enlisted twenty functional food plants with immunomodulatory and antiviral properties that have been reported to induce the immune system in several ways. These mainly include liquorice (Glycyrrhiza glabra L.), garlic (Allium sativum L.), tea (Camellia sinensis [L.] Kuntze), ginger (Zingiber officinale Roscoe), turmeric (Curcuma longa L.), pomegranate (Punica granatum L.), black pepper (Piper nigrum L.) and several others. ${ }^{4}$

For example, liquorice has been used as a medicinal and flavouring herb since ancient times. Traditionally, the dried roots are first crushed and then boiled to prepare an extract. The extract can be dried to a dark paste or powder and taken orally to treat different types of chronic infections. ${ }^{5}$ The root contains a saponin named 
glycyrrhizin, which is responsible for immunomodulation, antiviral and other biological activities. ${ }^{6}$ Innate immunity and adaptive immunity both greatly depend on the activity and function of the white blood cell (WBC) count and it is also evident that most of the immune cells are produced from haematopoietic stem cells of bone marrow. Raphael and Kuttan reported that mice treated with glycyrrhizic acid showed an increase in WBCs, bone marrow cellularity and $\alpha$-esterase positive cells. In addition, they analysed the humoral immune response by measuring the production of antibodies and the number of antibody-producing cells in the spleen, which were found to have increased in the treated mice. ${ }^{7}$ Moreover, the in-vitro results showed that glycyrrhizin promotes the growth response of splenic T-lymphocytes to anti-CD3 monoclonal antibodies or concanavalin A (Con A) through the improvement of interleukin-2 (IL-2) and IL-2 receptor (IL-2R) expression. ${ }^{8}$

Garlic has been one of the most popular herbal remedies since ancient times. It is believed that freshly crushed garlic mixed with honey or without can strengthen the immune system, as well as having antiviral and other biological properties, which might be due to the presence of several bioactive sulphur-containing compounds including sulphoxide, proteins and polyphenols. ${ }^{9}$ Several studies have suggested interesting beneficial effects of garlic on the immune cells and immunity in general. For example, Kuttan reported the immunostimulatory effects of sulphur compounds (diallyl sulphide, diallyl disulphide and allyl methyl sulphide) in mice. Amongst the compounds studied, mice treated with diallyl disulphide showed higher numbers of WBCs $\left(17,900\right.$ cells $\left./ \mathrm{mm}^{3}\right)$ and antibody titers than mice treated with other compounds. These compounds also significantly improved the bone marrow cellularity, the number of $\alpha$-esterase positive cells and the number of plaque-forming cells in the spleen. ${ }^{10}$ Other studies have reported that garlic protein fraction $4(\mathrm{~F} 4)$ improved the cytotoxicity of human peripheral blood lymphocytes (PBL) against NK sensitive (K562) and NK-resistant (M14) cell lines. F4 further improved IL2-induced and Con A-induced proliferation and their receptor expressions of PBL. ${ }^{11}$ Moreover, liquid garlic extract and protein fraction showed modulatory effects on macrophages and T-lymphocyte functions. These findings were further supported by the identification of three protein components of $\sim 13 \mathrm{kD}(\mathrm{QR}-1, \mathrm{QR}-2$ and QR-3) from garlic extract exhibiting mitogenic activity on certain immune cells that include, lymphocytes, mast cells and basophils. ${ }^{12}$

Similarly, other documented plants also possess immunostimulatory properties, such as curcumin derived from $C$. longa, which can interact with several types of immune cells, including dendritic cells, B- and Tlymphocytes, macrophages and cytokines ${ }^{13}$ and enhance the defence mechanism of the host. A black tea (C. Sinensis) decoction in cultured human peripheral mononuclear cells showed increased lymphoproliferative action at $72 \mathrm{~h} .{ }^{14}$

In human mononuclear cell cultures, green tea (also from $C$. Sinensis) extract showed increased production of neopterin (a potential marker for activation of cellmediated immunity) in unstimulated peripheral mononuclear cells. Whereas a reduction in neopterin was observed in cells stimulated with Con A, phytohemagglutinin and gamma interferon, confirming the immunomodulatory properties of green tea. ${ }^{15}$ These immunostimulatory properties of black tea and green tea are due to the presence of (-)-epigallocatechin gallate, quercetin and gallic acid in the leaves. ${ }^{16}$

Furthermore, Patil et al found that oral administration of ethanolic leaves extracts of the common fig (Ficus carica L.) ameliorated humoral and cell-mediated immune responses. ${ }^{17}$ Traditionally, this plant has also been used against several respiratory, gastrointestinal, inflammatory and cardiovascular. ${ }^{18}$ Moreover, methanolic extracts of mango (Mangifera indica L.) bark (rich in mangiferin) enhanced delayed-type hypersensitivity and humoral antibody titers, confirming its possible immunomodulatory properties. ${ }^{19}$ In-vivo oral administration of hexane leaves extract of mango increased the WBC count and the size of the thymus and spleen, indicating immunomodulation in WBCs and bone marrow hematopoietic cells. ${ }^{20}$ 
Table 1: List of plants with immunomodulatory and anti-viral properties

\begin{tabular}{|c|c|c|c|c|c|c|}
\hline Plant & Family & $\begin{array}{l}\text { English } \\
\text { Name }\end{array}$ & Part Used & Formulation & Compounds & References \\
\hline $\begin{array}{l}\text { Allium } \\
\text { cepa } \mathrm{L} .\end{array}$ & $\begin{array}{l}\text { Amarylli- } \\
\text { daceae }\end{array}$ & Onion & Bulb & $\begin{array}{l}\text { Crushed \& mixed } \\
\text { with honey }\end{array}$ & $\begin{array}{l}\text { Quercitin, thiosulfinates, and } \\
\text { anthocyanins }\end{array}$ & $\begin{array}{l}\text { Gansukh et } \\
\text { al., } 2017^{21}\end{array}$ \\
\hline $\begin{array}{l}\text { Allium sa- } \\
\text { tivum } \mathrm{L} \text {. }\end{array}$ & $\begin{array}{l}\text { Amarylli- } \\
\text { daceae }\end{array}$ & Garlic & Bulb & $\begin{array}{l}\text { Crushed \& mixed } \\
\text { with honey }\end{array}$ & $\begin{array}{l}\text { Diallyl disulphide, alliin, pol- } \\
\text { yphenols, } \\
\text { proteins (QR-1, QR- 2, and } \\
\text { QR-3) }\end{array}$ & $\begin{array}{l}\text { Anywar et } \\
\text { al., } \\
2019^{9}\end{array}$ \\
\hline $\begin{array}{l}\text { Berberis } \\
\text { vulgaris } \mathrm{L} .\end{array}$ & $\begin{array}{l}\text { Berberi- } \\
\text { daceae }\end{array}$ & Barverry & $\begin{array}{l}\text { Fruit, stem } \\
\text { and root }\end{array}$ & $\begin{array}{l}\text { Boiled extract and } \\
\text { poultice }\end{array}$ & Berbamine, berberine & $\begin{array}{l}\text { Kalmarzi et } \\
\text { al., } 2019^{22}\end{array}$ \\
\hline $\begin{array}{l}\text { Camellia } \\
\text { sinensis } \\
\text { (L.) } \\
\text { Kuntze }\end{array}$ & Theaceae & Tea Plant & Leaf & Boiled and drunk & $\begin{array}{l}\text { Catechins, quercetin, gallic } \\
\text { acid, theaflavin-3,3, -digal- } \\
\text { late }\end{array}$ & $\begin{array}{l}\text { Karimi et al., } \\
2016^{23}\end{array}$ \\
\hline $\begin{array}{l}\text { Carica pa- } \\
\text { paya } \mathrm{L} .\end{array}$ & $\begin{array}{l}\text { Carica- } \\
\text { ceae }\end{array}$ & $\mathrm{P}$ & $\begin{array}{l}\text { Fruit and } \\
\text { leaves }\end{array}$ & $\begin{array}{l}\text { Leaves are ground to } \\
\text { prepare juice; fruit } \\
\text { can be directly eaten }\end{array}$ & $\begin{array}{l}\text { Caricaxanthin, violaxanthin, } \\
\text { dehydrocarpine I and II and } \\
\text { cardenolide }\end{array}$ & $\begin{array}{l}\text { Radhakrish- } \\
\text { nan et al., } \\
2017^{24}\end{array}$ \\
\hline $\begin{array}{l}\text { Citrus au- } \\
\text { rantium } \mathrm{L} \text {. }\end{array}$ & Rutaceae & $\begin{array}{l}\text { Bitter or- } \\
\text { ange }\end{array}$ & $\begin{array}{l}\text { Fruit and } \\
\text { Peel }\end{array}$ & $\begin{array}{l}\text { Dried peel or fruit } \\
\text { juice }\end{array}$ & $\begin{array}{l}\text { Polysaccharides, polyphe- } \\
\text { nolic compounds }\end{array}$ & $\begin{array}{l}\text { Mannucci et } \\
\text { al., } 2018^{25}\end{array}$ \\
\hline $\begin{array}{l}\text { Curcuma } \\
\text { longa } \mathrm{L} \text {. }\end{array}$ & $\begin{array}{l}\text { Zingiber- } \\
\text { aceae }\end{array}$ & Turmeric & Rhizome & $\begin{array}{l}\text { Pounded, tincture, } \\
\text { powder }\end{array}$ & Curcumin & $\begin{array}{l}\text { Catanzaro et } \\
\text { al., } 2018^{26}\end{array}$ \\
\hline $\begin{array}{l}\text { Ficus } \\
\text { carica } \mathrm{L} .\end{array}$ & Moraceae & Fig & $\begin{array}{l}\text { Fruit, } \\
\text { leaves }\end{array}$ & $\begin{array}{l}\text { Decoction with } \\
\text { honey }\end{array}$ & $\begin{array}{l}\text { Terpenoids, anthocyanins, } \\
\text { steroids }\end{array}$ & $\begin{array}{l}\text { Patil et al., } \\
2010^{17}\end{array}$ \\
\hline $\begin{array}{l}\text { Glycine } \\
\max \quad(\mathrm{L}) \\
\text { Merr. }\end{array}$ & Fabs & & C & Cooked or roasted & $\begin{array}{l}\text { Isoflavones, flavonoids, phy- } \\
\text { tosterols, organic acid and } \\
\text { saponins }\end{array}$ & $\begin{array}{l}\text { Anitha et al., } \\
2015^{27}\end{array}$ \\
\hline $\begin{array}{l}\text { Glycyr- } \\
\text { rhiza gla- } \\
\text { bra } \mathrm{L} \text {. }\end{array}$ & Faba & dorice & Root & $\begin{array}{l}\text { Dried roots ex- } \\
\text { tracted. }\end{array}$ & Glycyrrhizin & $\begin{array}{l}\text { Smirnov et } \\
\text { al., } 2019^{28}\end{array}$ \\
\hline $\begin{array}{l}\text { Lycium } \\
\text { barbarum } \\
\text { L. }\end{array}$ & $\begin{array}{l}\text { Sola- } \\
\text { naceae }\end{array}$ & $\begin{array}{l}\text { Wolf- } \\
\text { berry }\end{array}$ & 10 & $\begin{array}{l}\text { Fresh fruit directly } \\
\text { eaten }\end{array}$ & $\begin{array}{l}\text { charide-protein com- } \\
\text { phenolic compounds }\end{array}$ & $\begin{array}{l}\text { By- } \\
\text { ambasuren et } \\
\text { al., } 2019^{29}\end{array}$ \\
\hline $\begin{array}{l}\text { Mangifera } \\
\text { indica } \mathrm{L} \text {. }\end{array}$ & $\begin{array}{l}\text { Anacardi- } \\
\text { aceae }\end{array}$ & $\mathrm{N}$ & $\begin{array}{l}\text { Bark, } \\
\text { leaves, } \\
\text { roots, } \\
\text { fruits, and } \\
\text { flowers }\end{array}$ & $\begin{array}{l}\text { Boiling or powder- } \\
\text { ing of bark, leaves, } \\
\text { root and flowers, } \\
\text { while fruit can be di- } \\
\text { rectly eaten }\end{array}$ & $\begin{array}{l}\text { Flavonoids, xanthones (Man- } \\
\text { giferin), phenolic acids, triter- } \\
\text { penes }\end{array}$ & $\begin{array}{l}\text { Amin et al., } \\
2019^{30}\end{array}$ \\
\hline $\begin{array}{l}\text { Morus } \\
\text { alba } \mathrm{L} \text {. }\end{array}$ & Moraceae & Mulberry & $\begin{array}{l}\text { Fruit leaf, } \\
\text { root }\end{array}$ & $\begin{array}{l}\text { Fruit juice, leaves } \\
\text { and root bark decoc- } \\
\text { tion or tea }\end{array}$ & $\begin{array}{l}\text { Carotene, vitamin B1, folic } \\
\text { acid, folic acid, vitamin D, } \\
\text { polyhydroxylated alkaloids, } \\
\text { glycoprotein, Anthocyanins, } \\
\text { benzofurans, stilbene }\end{array}$ & $\begin{array}{l}\text { Kim and } \\
\text { Chung, } \\
2018^{31}\end{array}$ \\
\hline $\begin{array}{l}\text { Nigella sa- } \\
\text { tiva } \mathrm{L} \text {. }\end{array}$ & $\begin{array}{l}\text { Ranuncu- } \\
\text { laceae }\end{array}$ & $\begin{array}{l}\text { Black } \\
\text { Cumin }\end{array}$ & Seeds & Roast and eat & Quinones, alkaloids, saponins & $\begin{array}{l}\text { Koshak et } \\
\text { al., } 2018^{32}\end{array}$ \\
\hline $\begin{array}{l}\text { Piper } \\
\text { longum L. }\end{array}$ & $\begin{array}{l}\text { Pipe- } \\
\text { raceae }\end{array}$ & $\begin{array}{l}\text { Long } \\
\text { pepper }\end{array}$ & $\begin{array}{l}\text { Fruit and } \\
\text { root }\end{array}$ & Deco & Piperine & $\begin{array}{l}\text { Kumar et al., } \\
2011^{33}\end{array}$ \\
\hline
\end{tabular}




\begin{tabular}{|l|l|l|l|l|l|l|}
\hline $\begin{array}{l}\text { Piper } \\
\text { nigrum L. }\end{array}$ & $\begin{array}{l}\text { Pipe- } \\
\text { raceae }\end{array}$ & $\begin{array}{l}\text { Black } \\
\text { pepper }\end{array}$ & fruit & $\begin{array}{l}\text { Dried and used as a } \\
\text { spice }\end{array}$ & Piperine & $\begin{array}{l}\text { Chaudry and } \\
\text { Tariq, 2006 }\end{array}$ \\
\hline $\begin{array}{l}\text { Prunus do- } \\
\text { mestica } \text { L. }\end{array}$ & $\begin{array}{l}\text { Pipe- } \\
\text { raceae }\end{array}$ & $\begin{array}{l}\text { Black } \\
\text { pepper }\end{array}$ & Fruit & Eaten fresh & $\begin{array}{l}\text { Anthocyanins, protocate- } \\
\text { chuic acid }\end{array}$ & $\begin{array}{l}\text { Rasne } \text { et al., } \\
2018^{35}\end{array}$ \\
\hline $\begin{array}{l}\text { Psidium } \\
\text { guajava } \text { L. }\end{array}$ & $\begin{array}{l}\text { Myr- } \\
\text { taceae }\end{array}$ & Guava & $\begin{array}{l}\text { Fruit, } \\
\text { shoots, } \\
\text { leaves }\end{array}$ & $\begin{array}{l}\text { Fruit can be directly } \\
\text { eaten. Decoction and } \\
\text { poultice of leaves } \\
\text { and shoots }\end{array}$ & $\begin{array}{l}\text { Phenolic, flavonoid, carote- } \\
\text { noid, terpenoid and triter- } \\
\text { penes }\end{array}$ & $\begin{array}{l}\text { Sriwilai- } \\
\text { jaroen } \text { et al., } \\
2012^{36}\end{array}$ \\
\hline $\begin{array}{l}\text { Punica } \\
\text { hranatum } \\
\text { L. }\end{array}$ & $\begin{array}{l}\text { Lyth- } \\
\text { raceae }\end{array}$ & $\begin{array}{l}\text { Pome- } \\
\text { granate }\end{array}$ & $\begin{array}{l}\text { Fruit, } \\
\text { Seeds, } \\
\text { Bark }\end{array}$ & $\begin{array}{l}\text { Fruit juice, a decoc- } \\
\text { tion of seeds, dried } \\
\text { bark }\end{array}$ & $\begin{array}{l}\text { Anthocyanins, fatty acids, al- } \\
\text { kaloids, vitamins }\end{array}$ & $\begin{array}{l}\text { Moradi } \text { et al., } \\
2017^{37}\end{array}$ \\
\hline $\begin{array}{l}\text { Zingiber } \\
\text { officinale } \\
\text { Roscoe }\end{array}$ & $\begin{array}{l}\text { Zingiber- } \\
\text { aceae }\end{array}$ & Ginger & Root & $\begin{array}{l}\text { Dried or roasted and } \\
\text { eaten with honey }\end{array}$ & $\begin{array}{l}\text { Essential oil, fibre, proteins, } \\
\text { fatty oils, carbohydrates }\end{array}$ & $\begin{array}{l}\text { Mahboubi, } \\
2019^{38}\end{array}$ \\
\hline
\end{tabular}

Note: I. Immunomodulatory properties of these plants are for overall body immune system, not for any disease, infection or organ; II. While antiviral properties are mostly against respiratory tract infectious viruses.

\section{Herbs with Antiviral Properties}

According to $\mathrm{WHO}$, respiratory tract infections are the leading cause of mortality amongst all infectious diseases. Viral diseases are life-threatening due to their rapid outbreak in developing as well as developed countries, whereas treating them is a huge challenge due to, easy adaptation, resistant viral pathogens and the emergence of new viral strains and the ineffectiveness of antibiotics. ${ }^{39}$ Bearing this in mind, several common and easily accessible functional food plants have been documented in this review that possesses immunomodulatory, antiviral (especially for respiratory tract infections) and other biological activities. For example, glycyrrhizin isolated from G. glabra was tested on SARS-CoV-infected patients admitted to the Clinical Centre of Frankfurt University, Germany. ${ }^{40}$ The results of this study showed that glycyrrhizin was the most effective inhibitor of SARS-CoV replication, with a selectivity index of 67 in Vero cells, compared with other tested compounds. Furthermore, this compound inhibited not only replication but also the adsorption and penetration of the virus. Although the exact mechanism by which glycyrrhizin inhibits SARSCoV adsorption, penetration and replication is unclear, a literature review revealed that it affects cellular signalling pathways, including protein kinase C, transcription factors and casein kinase II. Also, glycyr- rhizin enhances the production and expression of nitrous oxide (NO) in macrophages, which remarkably inhibits virus replication. ${ }^{41}$

In addition, glycyrrhizin possesses potent activity against the influenza A virus (H5N1), which is also an emerging virus and, like SARS-CoV, targeting the lungs. These viruses also have certain pathological similarities and differences. Previous studies have reported that a $100 \mu \mathrm{g} / \mathrm{ml}$ concentration of glycyrrhizin reduced the capacity of $\mathrm{H} 5 \mathrm{~N} 1$ to affect chemokine and interleukin (IL-6) production, as well as H5N1-induced apoptosis. ${ }^{42} \mathrm{H} 5 \mathrm{~N} 1$ replication was found to be enhanced at the high-mobility-group box1 (HMGB1) DNA binding site, but glycyrrhizin inhibited the polymerase activity of H5N1 by affecting HMGB1 binding to DNA. ${ }^{28}$ Therefore, this compound could be considered a potent antiviral agent and should be given serious attention. Moreover, the 3C-like protease of SARS-CoV is an important target for drug discovery and development because it is involved in proteolytic procession during the maturation of the virus.

Chen et al tested different compounds derived from $C$. Sinensis, including tannic acid, 3-isotheaflavin-3-gallate (TF2B) and several catechins, on 3CL protease activity. It has been suggested that catechins do not show inhibitory potential; however, both tannic acid $\left(\mathrm{IC}_{50}=\right.$ $7 \mu \mathrm{M})$ and TF2B $\left(\mathrm{IC}_{50}=3 \mu \mathrm{M}\right)$ were found to be potent inhibitors. These results suggest the potent role of the 
tea plant against SARS-CoV infection, but further investigation of its possible inhibitory action on the replication of $\mathrm{CoV}$ in cell culture might strengthen its claim to antiviral activity. ${ }^{43}$ Furthermore, curcumin derived from $C$. long $a$ decreased the yield of influenza virus by more than $90 \%$ in cell culture at $30 \mu \mathrm{M}$ concentration, which might have been because it affected the synthesis of viral proteins such as haemagglutinin, neuraminidase and matrix protein. ${ }^{44}$ Curcumin was also found to be effective against RSV, by inhibiting its replication and budding in the nasal epithelial cells of humans, and it also improved epithelial barrier activity. ${ }^{45}$ Similarly, other reported immunomodulatory functional food plants in this review also exhibit elevated antiviral activity, particularly against viruses causing respiratory tract problems, and so should be considered as potential antiviral agents.

\section{CONCLUSIONS}

Based on the knowledge of this review of literature study, we hypothesize that plants may help individuals to overcome the infection by (i) modulating the body's immune system, (ii) generating antiviral activity against the infection, and (iii) reducing other respiratory problems. A substantial number of plant extracts and phytochemicals have been explored for their antiviral property. Herbal preparations owing to their holistic approach strengthen the body's immune system, which in turn may help the body fight against invading infectious viruses. Herbal antiviral compounds, which are accessible and do not require laborious pharmaceutical synthesis are emerging as interesting alternatives in today's world of growing resistance to antiviral drug therapy.

Future Perspectives. Many promising herbal treatments exist for viral diseases with proof of their efficacy and safety in advanced clinical trials. However, a lot of work remains to be done to determine optimal treatments, doses and formulae for those herbal preparations. Although herbal plant preparations are widely used in several parts of the world, individually or in combination, data about the interactions of these medicinal plants in a living system is non-existent. Therefore, the traditional medicine practise should be clubbed with scientific research facilitating modern drug discovery from phytochemicals. Scientific data about detailed pharmacokinetic and pharmacodynamics of medicinal plants and their preparations should be made available to researchers and policymakers so that larger randomized multicenter clinical trials may be designed and conducted. By adopting such approaches, the idea of incorporating and implementing a particular herbal formulation in routine therapy may be transformed into reality.

\section{REFERENCES}

1. Alschuler L, Weil A, Horwitz R, Stamets P, Chiasson AM, Crocker R, Maizes V. Integrative considerations during the COVID-19 pandemic. Explore (New York, NY). 2020;16(6):354.

2. Pooladanda V, Thatikonda S, Godugu C. The current understanding and potential therapeutic options to combat COVID-19. Life sciences. 2020; 254:117765.

3. Mahady GB. Global harmonization of herbal health claims. The Journal of nutrition. 2001;131(3):1120S3S.

4. Yang F, Zhang Y, Tariq A, Jiang X, Ahmed Z, Zhihao Z, Idrees M, Azizullah A, Adnan M, Bussmann RW. Food as medicine: A possible preventive measure against coronavirus disease (COVID-19). Phytotherapy Research. 2020;34(12):3124-36.

5. Asl MN, Hosseinzadeh H. Review of pharmacological effects of Glycyrrhiza sp. and its bioactive compounds. Phytotherapy Research: An International Journal Devoted to Pharmacological and Toxicological Evaluation of Natural Product Derivatives. 2008;22(6):70924.

6. Seki H, Ohyama K, Sawai S, Mizutani M, Ohnishi T, Sudo H, Akashi T, Aoki T, Saito K, Muranaka T. Licorice $\beta$-amyrin 11-oxidase, a cytochrome $\mathrm{P} 450$ with a key role in the biosynthesis of the triterpene sweetener glycyrrhizin. Proceedings of the National Academy of Sciences. 2008;105(37):14204-9.

7. Raphael TJ, Kuttan G. Effect of naturally occurring triterpenoids glycyrrhizic acid, ursolic acid, oleanolic acid and nomilin on the immune system. Phytomedicine. 2003;10(6-7):483-9.

8. Zhang YH, Isobe K, Nagase F, Lwin T, Kato M, Hamaguchi M, Yokochi T, Nakashima I. Glycyrrhizin as 
a promoter of the late signal transduction for interleukin-2 production by splenic lymphocytes. Immunology. 1993;79(4):528.

9. Anywar G, Kakudidi E, Byamukama R, Mukonzo J, Schubert A, Oryem-Origa H. Medicinal plants used by traditional medicine practitioners to boost the immune system in people living with HIV/AIDS in Uganda. European Journal of Integrative Medicine. 2020; 35:101011.

10. Kuttan G. Immunomodulatory effect of some naturally occurring sulphur-containing compounds. Journal of ethnopharmacology. 2000;72(1-2):93-9.

11. Ishikawa H, Saeki T, Otani T, Suzuki T, Shimozuma K, Nishino H, Fukuda S, Morimoto K. Aged garlic extract prevents a decline of NK cell number and activity in patients with advanced cancer. The Journal of Nutrition. 2006;136(3):816S-20S.

12. Clement F, Pramod SN, Venkatesh YP. Identity of the immunomodulatory proteins from garlic (Allium sativum) with the major garlic lectins or agglutinins. International Immunopharmacology. 2010;10(3):31624.

13. Catanzaro M, Corsini E, Rosini M, Racchi M, Lanni C. Immunomodulators inspired by nature: a review on curcumin and echinacea. Molecules. 2018;23(11):2778.

14. Chattopadhyay C, Chakrabarti N, Chatterjee M, Mukherjee S, Sarkar K, Chaudhuri AR. Black tea ( $\mathrm{Ca}$ mellia sinensis) decoction shows immunomodulatory properties on an experimental animal model and in human peripheral mononuclear cells. Pharmacognosy research. 2012;4(1):15.

15. Zvetkova E, Wirleitner B, Tram NT, Schennach H, Fuchs D. Aqueous extracts of Crinum latifolium (L.) and Camellia sinensis show immunomodulatory properties in human peripheral blood mononuclear cells. International immunopharmacology. 2001;1(12):2143-50.

16. Kumar D, Arya V, Kaur R, Bhat ZA, Gupta VK, Kumar V. A review of immunomodulators in the Indian traditional health care system. Journal of Microbiology, Immunology and Infection. 2012;45(3):165-84.

17. Patil VV, Bhangale SC, Patil VR. Studies on immunomodulatory activity of Ficus carica. Int J Pharm Sci. 2010;2(4):97-9.

18. Duke JA. Handbook of medicinal herbs. CRC Press; 2002 Jun 27.

19. Makare N, Bodhankar S, Rangari V. Immunomodulatory activity of alcoholic extract of Mangifera indica
L. in mice. Journal of ethnopharmacology. 2001;78(23):133-7.

20. Shailajan S, Menon S, Kulkarni S, Tiwari B. Standardized extract of Mangifera indica L. leaves as an antimycobacterial and immunomodulatory agent. Pharmacognosy Communications. 2016;6(3).

21. Gansukh E, Muthu M, Paul D, Ethiraj G, Chun S, Gopal J. Nature nominee quercetin's anti-influenza combat strategy-Demonstrations and remonstrations. Reviews in medical virology. 2017;27(3): e1930.

22. Kalmarzi RN, Naleini SN, Ashtary-Larky D, Peluso I, Jouybari L, Rafi A, Ghorat F, Heidari N, Sharifian F, Mardaneh J, Aiello P. Anti-inflammatory and immunomodulatory effects of barberry (Berberis vulgaris) and its main compounds. Oxidative medicine and cellular longevity. 2019;2019.

23. Karimi A, Moradi MT, Alidadi S, Hashemi L. Antiadenovirus activity, antioxidant potential, and phenolic content of black tea (Camellia sinensis Kuntze) extract. Journal of Complementary and Integrative Medicine. 2016;13(4):357-63.

24. Radhakrishnan N, Lam KW, Norhaizan ME. Molecular docking analysis of Carica papaya Linn constituents as antiviral agent. International Food Research Journal. 2017 Aug 1;24(4).

25. Mannucci C, Calapai F, Cardia L, Inferrera G, D'Arena G, Di Pietro M, Navarra M, Gangemi S, Ventura Spagnolo E, Calapai G. Clinical Pharmacology of Citrus aurantium and Citrus sinensis for the Treatment of Anxiety. Evidence-Based Complementary and Alternative Medicine. 2018;2018.

26. Catanzaro M, Corsini E, Rosini M, Racchi M, Lanni C. Immunomodulators inspired by nature: a review on curcumin and echinacea. Molecules. 2018;23(11):2778

27. Anitha T, Parameswari K, Kishori B, Usha R. Evaluation of in vitro immunomodulatory effects of soyabean (Glycine max. 1) extracts on mouse immune system. International Journal of Pharmaceutical Sciences and Research. 2015;6(5):2112.

28. Smirnov VS, Zarubaev VV, Anfimov PM, Shtro AA. Effect of a combination of glutamyl-tryptophan and glycyrrhizic acid on the course of acute infection caused by influenza $(\mathrm{H} 3 \mathrm{H} 2)$ virus in mice. Voprosy virusologii. 2012;57(3):23-7.

29. Byambasuren SE, Wang J, Gaudel G. Medicinal value of wolfberry (Lycium barbarum L.). J Med Plants Stud. 2019;7(4):90-7. 
30. Amin AS. AL Dulaimi and Marwa AA AL Rawi, Antiviral Activity of Mangifera Extract on Influenza Virus Cultivated in Different Cell Cultures. J Pure Appl Microbiol. 2019;13(1):455-8.

31. Kim H, Chung MS. Antiviral activities of mulberry (Morus alba) juice and seed against influenza viruses. Evidence-Based Complementary and Alternative Medicine. 2018;2018.

32. Koshak AE, Yousif NM, Fiebich BL, Koshak EA, Heinrich M. Comparative immunomodulatory activity of Nigella sativa L. preparations on proinflammatory mediators: A focus on asthma. Frontiers in pharmacology. 2018; 9:1075.

33. Kumar S, Kamboj J, Sharma S. Overview for various aspects of the health benefits of Piper longum linn. fruit. Journal of acupuncture and meridian studies. 2011;4(2):134-40.

34. Chaudhry NM, Tariq P. Bactericidal activity of black pepper, bay leaf, aniseed and coriander against oral isolates. Pakistan journal of pharmaceutical sciences. 2006;19(3):214-8.

35. Rasne A, Sonwane V, Somani R, Kumthekar P. Evaluation of immunomodulatory activity of protocatechuic acid. J Res Notes. 2018; 1:1007.

36. Sriwilaijaroen N, Fukumoto S, Kumagai K, Hiramatsu H, Odagiri T, Tashiro M, Suzuki Y. Antiviral effects of Psidium guajava Linn. (guava) tea on the growth of clinical isolated H1N1 viruses: Its role in viral hemagglutination and neuraminidase inhibition. Antiviral research. 2012;94(2):139-46.

37. Moradi MT, Karimi A, Lorigooini Z, Pourgheysari B, Alidadi S. In vitro anti-influenza virus activity, antioxidant potential and total phenolic content of twelve Iranian medicinal plants. Marmara Pharmaceutical Journal. 2017;21(4).

38. Mahboubi M. Zingiber officinale Rosc. essential oil, a review on its composition and bioactivity. Clinical Phytoscience. 2019;5(1):1-2.

39. Adnan M, Tariq A, Mussarat S. A review on the antiviral activity of the Himalayan medicinal plants traditionally used to treat bronchitis and related symptoms. Journal of pharmacy and pharmacology. 2017;69(2):109-22.

40. Cinatl J, Morgenstern B, Bauer G, Chandra P, Rabenau H, Doerr HW. Glycyrrhizin, an active component of liquorice roots, and replication of SARSassociated coronavirus. The Lancet. 2003;361(9374):2045-6.
41. Jeong HG, Kim JY. Induction of inducible nitric oxide synthase expression by $18 \beta$-glycyrrhetinic acid in macrophages. FEBS letters. 2002;513(2-3):208-12.

42. Michaelis M, Geiler J, Naczk P, Sithisarn P, Ogbomo H, Altenbrandt B, Leutz A, Doerr HW, Cinatl J. Glycyrrhizin inhibits highly pathogenic H5N1 influenza A virus-induced pro-inflammatory cytokine and chemokine expression in human macrophages. Medical microbiology and immunology. 2010;199(4):2917.

43. Chen CN, Lin CP, Huang KK, Chen WC, Hsieh HP, Liang PH, Hsu JT. Inhibition of SARS-CoV 3C-like protease activity by theaflavin-3, 3'-digallate (TF3). Evidence-Based Complementary and Alternative Medicine. 2005;2(2):209-15.

44. Chen DY, Shien JH, Tiley L, Chiou SS, Wang SY, Chang TJ, Lee YJ, Chan KW, Hsu WL. Curcumin inhibits influenza virus infection and haemagglutination activity. Food Chemistry. 2010;119(4):1346-51.

45. Obata K, Kojima T, Masaki T, Okabayashi T, Yokota S, Hirakawa S, Nomura K, Takasawa A, Murata M, Tanaka S, Fuchimoto J. Curcumin prevents replication of the respiratory syncytial virus and the epithelial responses to it in human nasal epithelial cells. PLoS One. 2013 Sep 18;8(9): e70225.

\section{Source of Support: Nil Conflict of Interest: None Declared}

How to cite this URL: Keshamma E et al:An Overview On Role Of Ethnomedicine In Boosting Human Immunity To Combat Various Viral Diseases. International Ayurvedic Medical Journal \{online\} 2021 \{cited July 2021\} Available from:

http://www.iamj.in/posts/images/upload/1425_1432.pdf 